\title{
RHEOENCEPHALOGRAPHIC OBSERVATIONS IN MIGRAINE
}

\author{
B. G. L. Von Almay * \\ G. S. BAROLIN ** \\ F. L. JENKNER ***
}

Amongst the various forms of headache migraine is differentiated by three main criteria: (1) intense pain, hemicranic in type, of which (2) beginning and termination are clearly defined (meaning pain occurs in socalled fits or attacks) and which is (3) recurring periodically. It should be distinguished from continuous headache (vasomotor cephalea) even if the latter is only one-sided (hemicranic) and pulsating or of changing intensity as in waves. Typical and rare symptoms accompanying migraine such as vomiting, scotomata, vegetative disturbances and others we shall not discuss here since they have been presented separately (Barolin ${ }^{4}$ ).

The pathophysiological concept of migraine originated in studies of Graham and Wolff ${ }^{6}$ and was supported and extended later by Heyk ${ }^{7}$ and Pichler 20. Generally, one assumes a trifold vascular process consisting of (1) initial vasoconstriction, (2) overshooting vaso-dilation causing (3) stasis of blood in terminal vessels, occasionally accompanied by edematous transudation into surrounding tissue. Some assume abnormal patency of precapillary arterio-venous anastomoses to play a role in this mechanism.

Lately, several "vaso-neuro-active substances" have been described (mainly by Sicuteri ${ }^{26}$ and Saraiva ${ }^{22}$ ) and their role in the evolution of migraine was stressed. Inspite of these new humoral aspects which are being studied, the aforementioned aspect of vascular phenomena in the pathophysiology of migraine remains to be regarded as the most pertinent and ascertained concept at this time.

Therefore, it seems most convenient to have an indirect electrical method available for observing cerebro-vascular changes; rheoencephalography (REG) is a method which allows apparently to objectivate such changes. It should

From the 1st Div. of the Neurol. Hospital of the City of Vienna "Rosenhügel" (Director: Prof. Dr. H. Reisner) and the Neurological Clinic of the Hospital of Public Employees of the State of São Paulo (Head: Prof. Dr. R. Melaragno Filho): * Former head of the Section of Rheoencephalography at the Neurological Clinic, Hospital of Public Employees of the State of São Paulo, Brasil; ** Assistant at the First Division of Neurology Hospital of the City of Vienna "Rosenhügel"; *** Neurosurgeon and Docent, Graz University, Oesterreich.

Aknowledgement - Appreciation is expressed to the "Fundação de Amparo à Pesquisa do Estado de São Paulo" which has granted a travel stipend to the first author for specialization. 
be appropriate and interesting to compare the results obtained by this method with EEG-tracings in cases of proven migraine. Should our present concept of the pathophysiology of this disease be correct, one would expect changes in the realm of cerebral circulation primarily and only secondarily those relating to activity and metabolism of cerebral parenchyma. By its properties and definition, REG then should give better indications of our insight into pathology in cases of migraine than EEG may provide. Just the opposite should apply to cases of primarily metabolic disorders.

EEG-findings in migraine have been reported extensively (Barolin ${ }^{2}$ ); one may observe diffuse abnormality of bioelectrical activity of the brain (e.g. dysrhythmia with interspersed sharp waves) as well as localized changes, especially in recordings during an attack (focal character). Observations on REG also have been made (Orioli et al. ${ }^{18}$ ). In our study we shall compare relative merits of REG and EEG after having determined the value of REG as a diagnostic tool in cases of migraine.

\section{MATERIAL AND METHODS}

For examining the problem at hand, we recorded rheoencephalograms (REG) of all patients with suspected migraine that entered the neurological service of the "Neurological Hospital of the City of Vienna - Rosenhügel" during a 2-months period. 54 patients were subjected to REG during the pain-free interval period; in some of these cases hemodynamic observations were also possible during an acute episode of pain. These patients were part of a large group of persons suffering from migraine collected and controlled frequently in this hospital over an 11 year period as in- and out-patients. While hospitalized, they were completely and repeatedly examined physically and neurologically, including the entire range of clinical work-up. EEG had been recorded repeatedly in all cases. When indicated, carotid or/and vertebral or 4-vessel-angiography and pneumo-encephalography were done. Therefore, accuracy of diagnosis may safely be said to be of the highest standard possible to-day.

To judge changes in cerebral hemodynamics, indirect electrical monitoring ( $=$ REG) was chosen because this special application of the impedance technique was seen to be diagnostically valuable and reliable according to studies of many authors in many conditions. Basically, the principle of REG makes use of the changes of impedance due to circulatory events when applying an alternating current to parts of the body. Variations of impedance are depending on hemodynamic characteristics since impedance of blood is sufficiently better than impedance of other organs (muscle, adipose tissue, glands, bone, etc.) and the latter does not change (Mann ${ }^{15}$ ), while the volume of blood does change within a body segment with the propagation of the pulse wave.

Observations of the actual volume changes are called mechanical plethysmograms. For observing corresponding electrical changes, a sophisticated double bridge circuit (Doppelrheograph Dr. Schuhfried) was used. The relevance of this method for observing intracranial (= cerebral) circulation using skin surface electrodes has been discussed and shown previously (Jenkner ${ }^{8},{ }^{9}$ ). The advantage of the two-electrode system over other models has been demonstrated (Seipel ${ }^{25}$ ). Evidence of this may also be deduced from an ophthalmologic application of the impedance technique (Bettelheim ${ }^{5}$ ).

The REG-tracing has the shape of a phasic sinusoidal wave recurring with each heart action but delayed to the latter for such a time interval as is required for the propagation of the pulse wave to the organ or part of body in question. For 
the cerebrum, the normal time passing from R-wave of EKG to initial rise of REG is about $0,10 \mathrm{sec}$. and from $\mathrm{R}$-wave to main (= first) peak norma'ly equals about 0,25 sec. These time intervals do not show significant differences with sex but do correlate with the physiological age of cerebral vessels in the normal subject. Not unlike blood pressure recordings it has 2 peaks (the first one higher than the second one) separated by a notch.

Among the many criteria (Jenkner ${ }^{11}$ ) which have been used for evaluating REG-tracings two have shown to be interesting in respect to our question here and shall be mentioned in some detail. First of all there are temporal relations. The time at which the main (first) peak of the tracing occurs in relation to either initial rise of curve or R-wave of EKG may be compared to the normal values or between curves of the two hemispheres. Temporal relations of the two peaks of the REGtracing (i.e. time interval from first to second peak) may be indicative of pathology also. The second characteristic value useful for us here is the so-called relative pulse-(wave-) volume (Kaindl ${ }^{13}$ ). This is an index calculated from amplitude of curve (expressed in Ohms), basic value of overall resistive impedance (expressed in Ohms) and pulse rate/min. This index gives a good relative (semiquantitative) value for estimating pulse wave volume. Its meaning for cerebral application (REG) has been clarified only recently (Jenkner ${ }^{11}$ ).

Because of significant results from application of REG during an orthostatic stress test (Jenkner ${ }^{10}$ ) it was decided to include this testing in the diagnostic program of our patients. 43 of 54 patients were subjected to this procsdure. Recording of REG and EKG was done by means of a three channel direct recording apparatus. In the continuous tracings of the orthostatic stress test, only original REG-leads using one frontal (= ground) and one mastoid (= active) electrode for each hemisphere were registered with simultaneous EKG, while for the short routine recordings these were followed by registering derivative curves together with EKG.

\section{R E S U L T S}

The results of uur study will be presented in three parts. At first glance routine registration of $\mathrm{REG}$ in the interval period between pain episode (taking no longer than just a few minutes) revealed an abnormal shape of the tracing in only 7 of our 54 patients. An example of such a curve is shown in fig. 1 (comparison with normal and arteriosclerotic records). This same configuration was observed in $1 / 8$ of our patients constantly. It is characterized by low ( = late) position of the second peak in the catacrote part of an REG-phase.

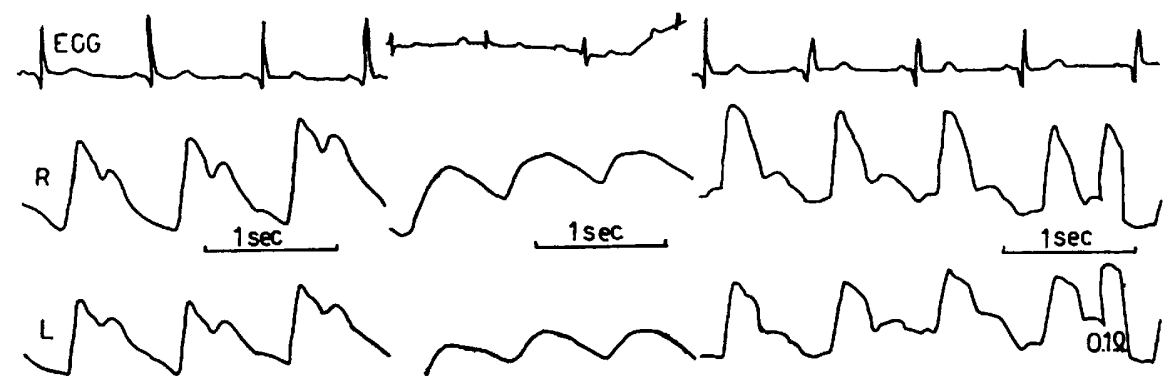

Fig. 1 - Sequence of REG-tracings of a normal subject (left), an arteriosclerotic subject (middle) and a person suffering from migraine (right). $E C G=$ electrocardiogram; $R(L)=R E G$ of right (left) hemisphere. 
As a second point of importance the results of calculating values for relative pulse wave volumes $\left(=P_{R}\right)$ during an orthostatic stress test (slightly modified) shall be presented. It becomes evident that irrespective of the time course of changes in blood pressure and pulse rates, values of $P_{R}$ deviated markedly and in a monotonously characteristic way from those typical curves these values show in either normals or subjects with hypotensive (or hypertensive) dysregulation when performing exactly the same type of orthostatic stress test (Schellong ${ }^{23}$ ). A comparison of the representative course of $P_{R}$-values during a Schellong-test as seen in patients displaying orthostatic hypotension with the course of values for a patient with migraine is shown diagrammatically in fig. 2. Here, the 27 yr. old patient is the one with hypotensive dysregulation while the $\mathbf{5 2} \mathrm{yr}$, old subject (G.H.) suffers from migraine. In the case of the latter patient $P_{R}$-values increase during standing up (even sitting) and deviate from a decrease of these values as is usually seen in hypotensive subjects. They also differ from the minimal tendency towards decrease seen in normal subjects. These differences will have to be explained.

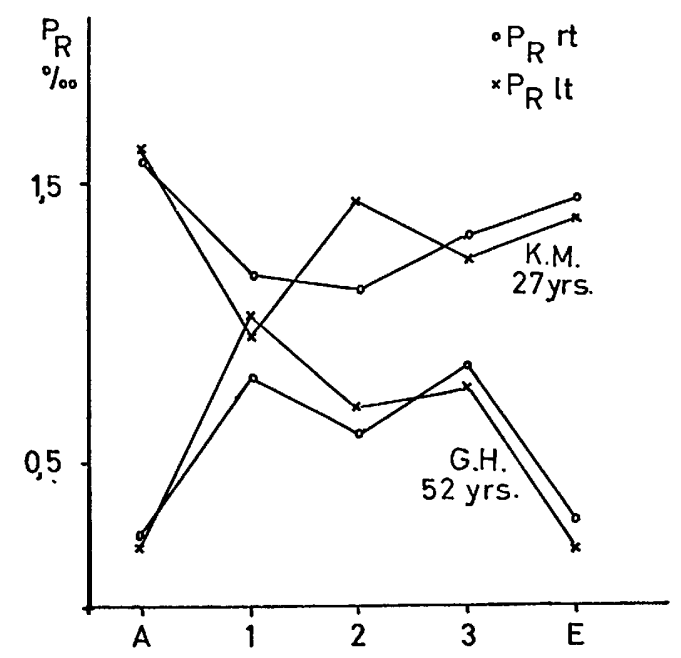

Fig. 2 - Diagram showing course of relative pulse wave volume $\left(P_{R}\right)$ in promille during orthostatic stress test $(A=$ resting horizontally; 1 = immediately after rising to erect position; $2=5$ min. after rising; $3=10 \mathrm{~min}$. after rising; $E=$ after ass $u$ ming horizontal position). Right (o) and left $(x)$ hemispheres are presented separately for 2 patients: $K . M ., 27$ yrs, dg.: hypotension; G.A., 52 yrs, dg. migraine.

Having observed REG changes representing disturbances in hemodynamics in cases of migraine to occur in a fairly large percentage of cases (just as had been observed by others, e.g. $65 \%$ : Orioli et al. ${ }^{18}$ ), comparison of these findings with incidence of pathological EEG reports becomes rather important. Such a comparison might help to establish the relative value of both these examinations for diagnosing migraine. With this in mind, it is of importance to see (in addition to those cases, where both REG + EEG are pathological and in accordance with clinical signs), the frequency of correct REG-findings with incorrect EEG-findings 
(or vice-versa) and how these correlate with other investigations and the clinica) picture. We thought it relevant enough to compare lateralizing pathology by EEG and REG and used the correctness (or incorrectness) of the detected side of pathology as our criterion. As seen from data in the table 1, REG-tracings agreed three times as well with the correct clinical condition than did EEG-tracings. In 3 cases both examinations deviated from the clinical picture.

\begin{tabular}{llll}
\hline Comparisons & REG $=$ clin. signs & EEG = clin. signs & EEG $=$ REG \\
& EEG not correct & REG not correct & clin. signs differing
\end{tabular}

\begin{tabular}{llll}
\hline Case numbers & $8,13,17,18,29$, & $25,27,33$ & $20,49,51$ \\
& $36,43,44,54$
\end{tabular}

Table 1 - To compare correctness of REG versus EEG and clinical signs.

Finally it may be interesting to compare EEG and REG results of this group of migraine patients with patients having similar affections of cerebral circulation. A group of patients with Menière's disease and syndrome and a group of proven arteriosclerotic changes in cerebral vessels both studied at a previous occasion (Jenkner and Vojacek ${ }^{12}$ ) was used. The results of this comparison is presented as the table 2 .

\begin{tabular}{|c|c|c|c|c|c|c|c|c|}
\hline \multirow{3}{*}{ Condition } & \multirow{3}{*}{$\begin{array}{c}\text { Nr. of } \\
\text { cases }\end{array}$} & \multicolumn{5}{|c|}{ EEG } & \multicolumn{2}{|c|}{ REG } \\
\hline & & \multicolumn{2}{|c|}{ abnormality } & \multirow{2}{*}{$\begin{array}{c}\text { susp. } \\
\text { epilepsy }\end{array}$} & \multirow{2}{*}{$\begin{array}{l}\text { other } \\
\text { pathol. }\end{array}$} & \multirow[t]{2}{*}{ normal } & \multirow[t]{2}{*}{ pathol. } & \multirow[t]{2}{*}{ normal } \\
\hline & & focal & $\begin{array}{c}\text { gene- } \\
\text { ral }\end{array}$ & & & & & \\
\hline Migraine & 54 & 6 & 25 & - & - & 11 & 46 & 8 \\
\hline Menière & 49 & 5 & $\mathbf{3}$ & 2 & - & 27 & 49 & 一 \\
\hline Arteriosclerosis & 40 & 11 & 2 & 1 & 1 & 17 & 40 & - \\
\hline
\end{tabular}

Table 2-Comparing pathology of REG and EEG-tracings in cases of migraine, Menière and arteriosclerosis (figures for Menière syndrome and arteriosclerosis from Jenkner \& Vojacek $\left.{ }^{12}\right)$.

\section{I S C U S I O N}

To judge changes in cerebral hemodynamics the indirect electrical monitoring (REG) was selected because this special application of the impedance technique was seen to be diagnostically valuable and reliable according to the studies of many authors in the following conditions: determining the biological age of cerebral vessels; cerebral arteriosclerosis; arterial stenosis and occlusion (except of minute vessels; Schreiber ${ }^{24}$ ); a.-v. shunting, as in angiomata, carotid-cavernous fistulas, etc.; cerebral trauma (contusion 
and distinction of it from hematoma); cerebral compression (also from abscess); clarifying causes of stroke (with of without occlusion/stenosis of vessels or hemorrhage); objectivating causes of cerebro-vascular insufficiency; testing of various physiclogical and pathological conditions such as carotid compression (for determining lateralisation of dependence on carotid blood supply and sufficiency of collateral flow), lack of $\mathrm{O}_{2}$ (athletic stress, e.g. diving) and increase of $g$ (by increasing acceleration in a human centrifuge) It must be mentioned that few authors have reported the method not to be suitable for some of these purposes (e.g. Perez-Borja and Meyer ${ }^{19}$ ). However, in most of these circuiting of apparatus and "selection" of patients may be subject to criticism and the approximate relation of affirmatory to negative reports in the literature is about 350 to one at this time.

At first let us regard the deviation of the shape of an REG-tracing from a normal record seen in a routine REG of only 7 migrainous patients. The later occurrence of the second peak (i.e. lower on the catacrote slope; fig. 1) was not seen in any other well defined clinical condition studied. Such a shape may be postulated mathematically only (applying the theory of REG to a practical problem; Roth ${ }^{21}$ ) if there are existing certain criteria of damping (within the skull) of the pulse wave (initiated by cardiac action) as they should be present in cases of low CSF-pressure or decreased amount of CSF within the intracranial space. Because of the small number of cases in which this shape was observed one should not specify this as a typical shape.

The control of the mathematically postulated condition comes when we regard the later (and lower on the catacrote branch of the tracing) occurring notch and second peak as a correlate of decreased peripheral vascular resistance, contrary to earlier (i.e. higher on declining slope of REG occurring notch in cases of increased peripheral vascular resistance, which was mathematically postulated by Kenner ${ }^{14}$ ). Thereby a slower propagation of the pulse wave in cases of migraine would have to be postulated. To judge this with the slightest degree of significance our number of observations is far too small. However, we did compare the respective time intervals from our 7 cases with the same values of 178 average normal REG-tracings (evaluated by computer) using 100 phases of each subject and the values for migraine patients were higher, meaning the impression of a slower propagation of pulse wave was conveyed.

Comparing the average of 100 phases of each of 246 arteriosclerotic patients, which should have a higher speed of propagation of pulse wave the mean of this same time interval was shorter (even though not significantly so) than in 178 normal REG's.

Other changes of shape of REG phase observed among our patients were: 12 cases of a form rather typical for arteriosclerotic subjects (moderate to severe changes) and 8 normal tracings. Once only a shape was seen known to signify a vasospastic state; here, a higher than normal pulse wave velocity was observed together with an earlier (higher on the declining slope of REG) second peak. 
Summarizing this part of our results it seems that there is a group of migraine patients in which the mathematical analysis of REG suggests that they have decreased peripheral vascular resistance. We could see only one case where increased peripheral vascular resistance was deduced from REGanalysis. Another group showed arteriosclerotic changes which might of course cover up and thereby make impossible to detect other REG-changes. To correlate the respective changes seen in peripheral vascular resistance with the diagnosis of migraine would require confirmation of our results on a much larger number of cases. After this discussion of abnormal findings in the timing of details of an REG-record we proceed to regarding findings of REG-tracings during an orthostatic stress test on our patients.

First of all, it should be mentioned that the values for relative pulse wave volume $\left(P_{R}\right)$ calculated from routine REG (short time registration) of our migraine patients were found to be subnormal. This supplements the low incidence of rather abnormal shape of REG observed but must be and can be differentiated from the decrease of $P_{R}$ found in cases of CVI of varying causes. A good means of such differentiation is calculating and diagrammatically sketching the $P_{R}$-values for the various parts of a continuous tracing obtained during performance of an orthostatic stress test. Migraine patients show a very much different type of course of the $P_{R}$-values during such a test than is seen in all other pathological states and normals. 43 of our 54 patients were submitted to this test and the following courses of $P_{R}$-values were seen: 13 times the course could be called normal, 4 times it was judged as pointing to hypotensive dysregulation and 26 times a course was found which is shown in fig. 2 and could be termed "migrainoid". Since not only the latter cases but also those 4 showing hypotensive trends belonged to the group of proven migraine, $2 / 3$ of the courses of $P_{R}$-values showed what was called "migrainoid" characteristics and this asks for further discussion and explanation.

Amongst the possible mechanisms responsible for such a course the one most likely to provide an explanation presupposes that the sensitivity of reflexes regulating hemodynamics is very high in patients suffering from migraine. These patients most commonly are hypotensive. Because of this hypersensitivity, a further small drop in (brachial artery) blood pressure will be overcompensated and an increase of relative pulse wave volume is resulting. Otherwise $P_{R}$ would decrease or at least stay stable during the orthostatic period of the test. Therefore it does not surprise to find initial $P_{R}$-values low as is true for all hypotensive subjects.

These two findings just discussed suffice to achieve better results of evaluation of REG-tracings than was evident from EEG-findings. Already in the introduction we postulated that any pathological vascular mechanism must better show in an (even indirect) study of hemodynamics than in an examination based on bioelectrical activity (or metabolism). Therefore it is not surprising that in studies on cases of Menière and cerebral arteriosclerosis, equivalent better diagnostic value was observed for REG than for 
EEG. Of course, one clearly understands that 50\% of EEG's were pathological in arteriosclerotic patients because of longer standing of the organic pathology. In this condition, $100 \%$ of REG records were pathological. On the other hand, in Menière's attacks, only a $25 \%$ rate of pathological EEGfindings was seen while no REG tracings were normal. Our study of REG pathology in these 2 last conditions therefore is confirmed in its differential diagnostic value by the observations in cases of migraine, where $73,6 \%$ of EEG and $82,7 \%$ of REG were pathological.

This study then shows that REG as a technique supplying insight into an aspect of cerebral circulatory events provides a better basis for diagnostic evaluation of cases of migraine than does EEG. The small number of our interval tracings on routine REG examinations ( $1 / 8$ of total number of cases studied) expresses the complexity of the problem: the supply areas of both carotid and vertebral arteries as well as possibly the extracranial vascular bed (Anthony et al. ${ }^{1}$ ) may be involved in the pathophysiology of migraine.

Our observations on the course of relative pulse wave volume during a certain circulatory stress and their explanation by overshooting reflex regulation provides a basis for understanding of the largely unsatisfactory therapeutic effect sympathomimetic drugs have in cases of migraine. Generally, it is regarded as typically for migraine that in the many hypotensive migrainous patients derivatives of synephrine usually are of little avail and fail to normalize blood pressure. This study gives an experimentally founded explanation why this is so.

From these empirical observations alone one should not deviate too much into theoreticizing suppositions; however, it is very satisfying that REG apparently allows to objectivate the cerebrovascular state also in migraine. Our results are ascertained by comparison with series of studies in similar conditions. Now it seems that such studies may also be applicable to and useful in following and evaluating therapeutic results especially in view of their harmlessness which invites repetition.

\section{S U M M A R Y}

The pathophysiological concept of migraine presently held attributes the major changes to vascular factors. Therefore, it seemed appropriate to use rheoencephalography to test cerebral hemodynamics in cases of migraine. This very harmless and well suited method revealed: (1) on routine tracings during the painless intervall only $1 / 7$ of the cases showed significant changes, while more than $2 / 3$ could be classified with the help of an orthostatic stress test under REG-observation; (2) REG is more often correct for diagnosis than EEG and this does not surprise since REG monitors cerebral hemodynamics directly while EEG records activity for parenchyma and thus only secondarily depends on circulation; (3) similar conditions were previously seen in Menière's disease where EEG also is less efficient than REG. 
According to the results of this study, it should be interesting to include REG in the work-up of migrainous patients. In these and under similar conditions, REG will be of diagnostic value.

Reoencefalografia: observações na enxaqueca

No conceito fisiopatológico da enxaqueca atribui-se grande importância às alterações vasculares. Por esta razão empregamos a reoencefalografia, método simples e inócuo que nos pareceu o mais adequado para estudar a hemodinâmica cerebral em casos de hemicrânia. Nossas conclusões foram as seguintes: (1) nos traçados reoencefalográficos de rotina encontramos, em apenas $1 / 7$ dos casos, alterações qualitativas e quantitivas significantes no periodo intercrítico da enxaqueca, ao passo que mais de $2 / 3$ dos traçados podiam ser classificados como patológicos e característicos, desde que utilizássemos o teste ortostático de Schellong; (2) a reoencefalografia parece ser mais precisa do que a eletrencefalografia para o diagnóstico de hemicrânia; êste fato é compreensível pois o reoencefalograma registra diretamente a hemodinâmica cerebral, enquanto que o eletrencefalograma registra a atividade bioelétrica do parênquima a qual, por sua vez, apenas secundàriamente depende de circulação sangüínea; (3) resultados semelhantes foram, também, observados em casos de sindrome de Menière nos quais a eletrencefalografia seria, também, menos útil que a reoencefalografia.

De acôrdo com êstes resultados, parece-nos ser lícito sugerir a inclusão da reoencefalografia na rotina e no contrôle terapêutico de pacientes com hemicrânia. Nesta e em outras condições similares a reoencefalografia é um método paraclínico de alto valor.

\section{R E F E R E N E S}

1. ANTHONY, M.; HINTERBERGER, H. \& LANCE, J. W. - The possible relationship of serotonin to the migraine syndrome. Res. Clin. Stud. Headache. Vol. 2:29. Karger, Basel-New York, 1969.

2. BAROLIN, G. S. - Atypische Migräne: Klinik, Differential-diagnose, EEG. Wien. Klin. Woschr. 75:293, 1963.

3. BAROLIN, G. S. - Familiäre paroxysmale Halbseitenanfälle mit und ohne Kopfschmerzattacken. Schweiz. Arch. Neurol. Neurochir. Psych. 99:15, 1967.

4. BAROLIN, G. S. - Migräne. Facultas Verlag, Wien, 1968.

5. BETTELHEIM, H. - Die Rheographie in der augenärztlichen Kreislaufdiagnostik. Klin. Monatsbl. f. Augenheilkunde 150:805, 1967.

6. GRAHAM, J. \& WOLFF, M. - Mechanisms of migraine headache and action of ergotamine tartrate. Arch. Neurol. Psychiat. (Chicago) 39:737, 1938.

7. HEYK, H. - Der Kopfschmerz. 3. Aufl., Georg Thieme Verlag, Stuttgart, 1964.

8. JENKNER, F. L. - Uber den Wert des Schädelrheogrammes für die Diagnose cerebraler Gefäbstörungen. Wien. Klin. Woschr. 69:619, 1957.

9. JENKNER, F. L. - Rheoencephalography. Charles C. Thomas, Springfield (Illinois), 1962. 
10. JENKER, F. L. - Uber das Verhalten der cerebralen Haemodynamik während eines orthostatischen Kreislaufbelastungsversuches. Z. Kreislaufforsch. 55:998, 1967.

11. JENKNER, F. L. - Rheoencephalography: Present Status. In Progress in Brain Research: W. Luyendijk, ed. Vol. 30, pág. 127. Elsevier Publishing Co., Amsterdam-London-New York, 1968.

12. JENKER, F. L. \& VOJACEK, E. - Vascular studies in Menière's syndrome and disease. Acta oto-laryngol. 64:427, 1967.

13. KAINDL, F.; POLZER, K. \& SCHUHFRIED, F. - Die Amplitudenauswertung des Rheogramms. Wien. Z. inn. Med. 40:175, 1959.

14. KENNER, Th. - Die Beziehung zwischen dem endsystolischen Drlick und dem peripheren Widerstand am schlauchmodell. Z. Kreislauforsch. 48:570, 1959.

15. MANN, H. - Study of peripheral circulation by means of alternating current bridgc. Proc. Soc. Exper. Biol. Med. 36:670, 1937.

16. MOSKALENKO, Yu. E. - Dynamies of the brain blood volume under normal conditions and gravitational stresses. Acad. Sci. USSR. Problems of Space Biology. Vol. V. 1967. Pg. 218.

17. NOEL, G.; PIRAUX, A. \& JAQUY, J. - Le rhéogramme crânien et sa dérivée en pathologie cérébrale. Acta Neurol. psychiat. Belg. 67:1153, 1967.

18. ORIOLI, G; PAZZAGLIA, P. \& MANTOVANI, M. - A rheographic and polygraphic study in migraine. In REG and Plethysmographical Methods. Excerpta Med. Monogr., 1969, pg. 164-169.

19. PEREZ-BORJA, C. \& MEYER, J. S. - A critical evaluation of rheoencephalography on control subjects and in proven cases of cerebrovascular disease. $\mathrm{J}$. Neurol. Neurosurg. Psychiat. 27:66, 1964.

20. PICHLER, E. - Der Kopfschmerz. Springer Verlag, Wien, 1952.

21. ROTH, E. - Personal communication.

22. SARAIVA, S. - Poliptídeos farmacològicamente ativos e diâmetro de artérias piais: estudo experimental com vasopressina, ocitocina, bradicinina e neurocinina. Tese de doutoramento. Faculdade de Medicina Univ, de São Paulo. Arq. Neuro-Psiquiat. (São Paulo) 23:1, 1965.

23. SCHELONG, F. - Regulationsprüfung des Kreislaufes. Darmstadt, 1954.

24. SCHREIBER, H. - Comparative Investigations of Carotid Pulse Sphygmograph, Fundus Appearances and Rheoencephalography, Pg. 208-216 In REG and Plethysmographical Methods, Excerpta Med. Monogr. 1969.

25. SEIPEL, J. - The influence of electrode size and material on the rheoencephalogram. Proc. Internat. Conf. Bioelectr. Impedance. N. Y. Acad. Sci., New York, 1969.

26. SICUTERI, F. - Vasoneuroactive Substances and their Implication in Vascular Pain. Research and Clinical Studies in Headache. S. Karger, Basel, 1967.

Dr. Barolins and Dr. Jenkners address: Fichtnergasse 22 - A-1130 Wien XIIIOesterreich. 